\title{
EVALUATION OF HEPATOPROTECTIVE POTENTIALS OF METHANOL EXTRACT OF TEPHROSIA VILLOSA AGAINST THIOACETAMIDE INDUCED LIVER TOXICITY IN ALBINO RATS
}

\author{
PINKEY RAWAL ${ }^{1}$, RAMESH $C^{2 *}$, SOMA PRAMANIK ${ }^{1}$, SHABANA ${ }^{3}$ \\ ${ }^{1}$ Department of Pharmaceutical Chemistry, East West College of Pharmacy, Bengaluru, Karnataka, India. ${ }^{2}$ Department of Pharmacology, \\ East West College of Pharmacy, Bengaluru, Karnataka, India. ${ }^{3}$ Department of Pharmacognosy, East West College of Pharmacy, Bengaluru, \\ Karnataka, India. Email: rameshcology80@gmail.com \\ Received: 15 August 2021, Revised and Accepted: 25 September 2021
}

ABSTRACT

Objective: The present study was conducted to determine the hepatoprotective potentials of methanol s extracts of Tephrosia villosa leaves against thioacetamide (TAA) induced liver damage in rats.

Methodology: The acute oral toxicity study was conducted as per OECD guidelines, and the extract was proved to be safe up to the dose of $2000 \mathrm{mg} / \mathrm{kg}$. The total duration of the study was 21 days, and animals were divided into six groups. Hepatotoxicity was induced in the animals of all groups except normal control by single dose administration of TAA $(100 \mathrm{mg} / \mathrm{kg})$ at 1 st day of the study followed by animals were treated daily with standard drug silymarin and methanol extract of T. villosa $(100 \mathrm{mg} / \mathrm{kg}, 200 \mathrm{mg} / \mathrm{kg}$ and $400 \mathrm{mg} / \mathrm{kg})$ to respective groups for 21 days. Variations in biochemical parameters such as alanine aminotransferase, aspartate aminotransferase, alkaline phosphatase, total bilirubin, direct bilirubin, albumin, total protein, ions and others parameters such as clotting time and weight of the liver were considered to determine beneficial effect of the extract. At the end of the study liver samples were collected and subjected to histopathological evaluation.

Results: In control animals treated with TAA alone, there were variations in the above mentioned parameters. However in the animals treated with methanol extract and standard drug silymarin, all the parameters were normal possibly due to their beneficial property in protecting the liver against TAA induced hepatotoxicity.

Conclusion: The results obtained in the above study suggesting that, the methanol extract of T. villosa possess significant hepatoprotective activity.

Keywords: Hepatoprotective activity, Tephrosia villosa, Thioacetamide, alanine transferase, aspartate transferase and Bilirubin.

(C) 2021 The Authors. Published by Innovare Academic Sciences Pvt Ltd. This is an open access article under the CC BY license (http://creativecommons.org/ licenses/by/4.0/) DOI: http://dx.doi.org/10.22159/ajpcr.2021v14i11.43033. Journal homepage: https://innovareacademics.in/journals/index.php/ajpcr

\section{INTRODUCTION}

The liver disorder has become one of the common health problems worldwide due to exposure human life to various drugs, alcohol, toxins, and hepatitis viral infections [1]. Liver is vital organ of biliary system required to maintain important homeostasis of the body due its various responsibilities. The liver has got its own importance in the physiological system such as metabolism of ingested substances such as carbohydrates, lipids, proteins, blood coagulation, detoxification process, and immunomodulation are the primary functions of the liver [1]. The liver injury is associated with distortion of these metabolic functions [2] and results into disturbance in homeostasis of the body. However, till now, there is no truly satisfactory liver protective drug in the modern system of medicine which is effective and safe. Hence, natural remedies from medicinal plants are considered to be effective and safe alternative drugs for the treatment of hepatotoxicity and a number of medicinal plants in Ayurveda, the Indian system of medicine, are recommended for the treatment of liver disorders [3].

About 600 commercial preparations with claimed liver protecting activity are available all over the world. About 100 Indian medicinal plants belonging to 40 families are used for herbal formulation [4]. The Tephrosia villosa is native to India and it is medicinally important and used in traditional system for the treatment of liver ailments [5]. The T. villosa is commonly known as Shankhpushpi and used in Ayurvedic system of medicine as memory enhancer, neuroprotective [6], and treatment many ailments. The leaves of this plants contains alkaloids, flavonoids, tannins and phenols [7] and scientifically proved for its antidiabetic [9] antiulcer [6], antianxiety [10], antioxidant [11], and many other pharmacological activities. The phytoconstituents of plant leaves are capable of reducing liver toxicity due to their antioxidant properties, but the plant has not been scientifically investigated for evaluation of hepatoprotective activity [11]. In view of this, the present study was undertaken to investigate the hepatoprotective activity of methanol extracts of T. villosa (TVME) leaves against thioacetamide (TAA) induced liver damage in rats.

\section{METHODS}

\section{Chemicals}

All the chemicals and reagents used in the presnt study were of analytical grade. The hepatotoxin TAA was procured from Sigma-Aldrich Chemical Pvt. Ltd., Bangalore, and standard drug silymarin was obtained from the Himalaya Drug Company, Bangalore (Nice Chemicals Pvt. Ltd., Bangalore), and Estimation Kits for aspartate aminotransferase (AST), alanine aminotransferase (ALT), alkaline phosphatase (ALP), serum bilirubins, sodium, potassium, and glutathione peroxidase (GPX) were obtained from SPAN diagnostics.

\section{Preparation of plant extract}

The plant leaves of T. villosa Linn were collected in Sri Venkateswara University, Tirupati, Andhra Pradesh and authenticated by Dr. Madhava Chetty, Department of Botany, Sri Venkateswara University, Tirupati, Andhra Pradesh and authenticated by Dr. Madhava Chetty. The plant leaves were shade dried and powdered; the coarse powder was subjected to successive extraction with petroleum ether and methanol (70\%). Then, marc was subjected to extraction using chloroform water as solvent [12]. 
Preliminary phytochemical studies

The methanol extract of T. villosa was subjected to preliminary phytochemical investigation as per the procedure described by Khandelwal. Dragon Droff's reagent was used to detect presence of alkaloids. Neutral ferric chloride was used to detect phenolic compounds that appear in the form of blue spots. Folin-Ciocalteu test and Fiegel test was used to detect flavonoids and glycosides, respectively $[13,14]$.

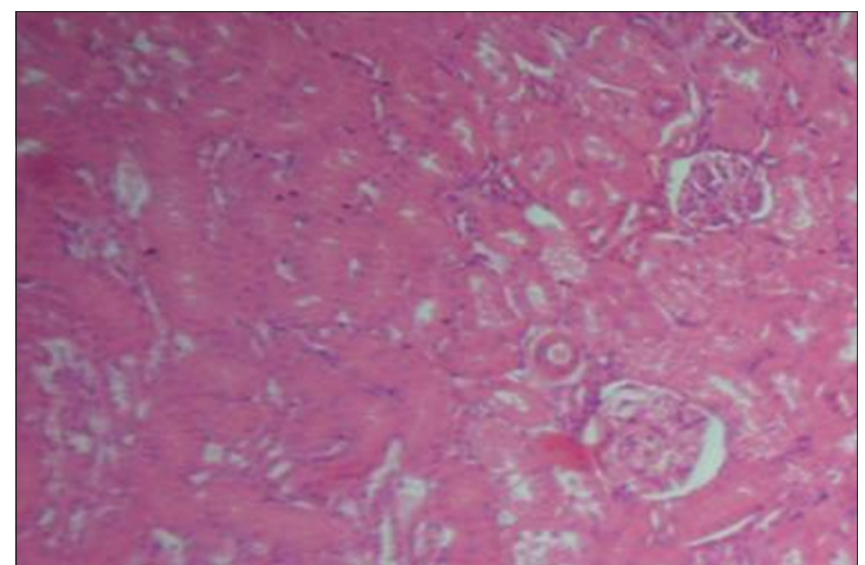

Figure 1: Histopathology of liver sample from normal group

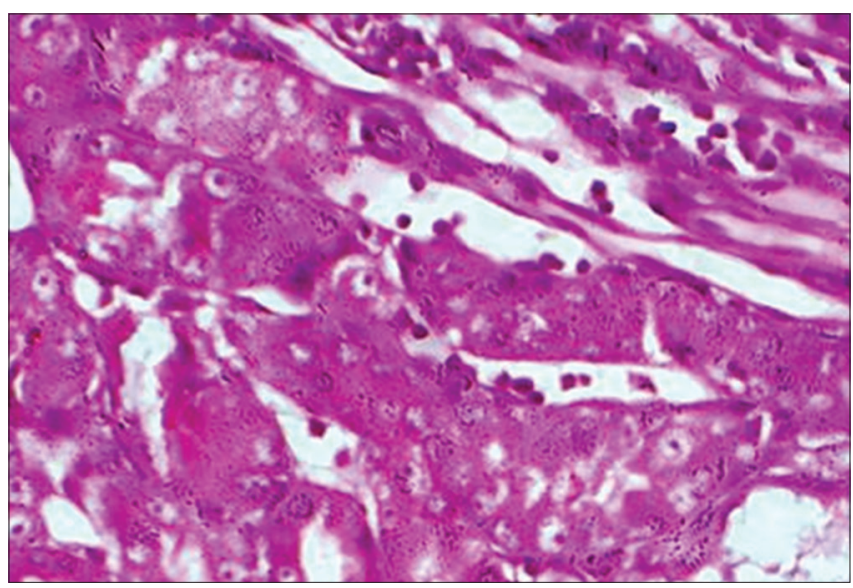

Figure 2: Histopathology of liver sample from toxic group

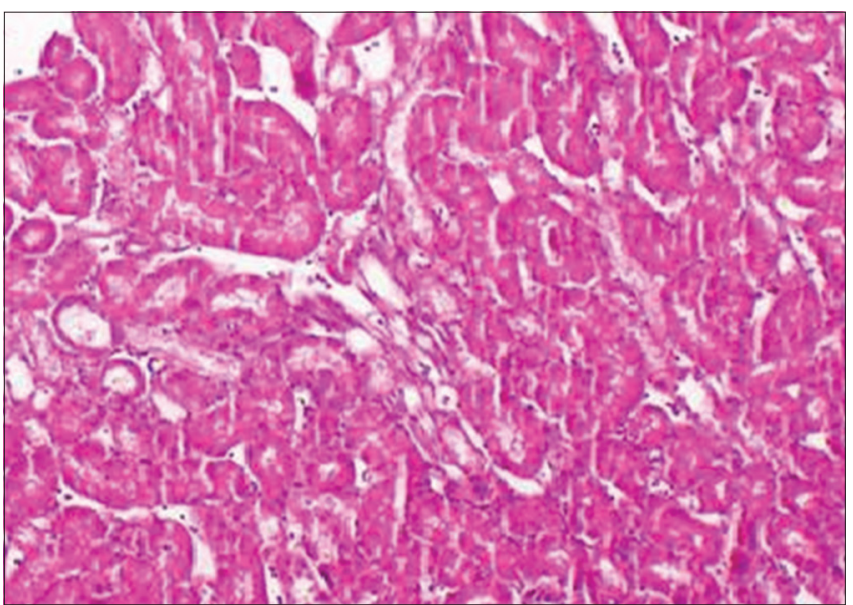

Figure 3: Histopathology of liver sample from standard group
Animals

Healthy Adult Wistar rats weighing 180-200 was purchased from the Venkateswara Enterprises, Bangalore. The animals were housed in well ventilated cage and animals had $12 \mathrm{~h}$ day and night schedule with temperature between $28 \pm 2^{\circ} \mathrm{C}$. The animals were housed in large spacious hygienic cages during the course of the experimental period. The animals were allowed free access to standard laboratory pellets and drinking water ad libitum. The study protocol was approved by an Institutional Animal Ethics Committee, IJAHSM (Ref.no.IJAHSM/ IAEC/2014/03) with the permission from committee for the purpose of control and supervision of experiments on animals, Ministry of Social Justice and Empowerment, Government of India.

\section{Determination of acute oral toxicity}

Acute oral toxicity of methanol (TVME) extracts of T. villosa was done according to the OECD guidelines No. 423. The overnight fasted mice were divided into four groups, each group consisting of three female animals. The methanol extract (TVME) of T. villosa was given in various doses $(5,50,300$, and $2000 \mathrm{mg} / \mathrm{kg}$ b.w.) by gastric incubation with a syringe. After administration of the extract, the animal were observed continuously for the first $2 \mathrm{~h}$ and at $24 \mathrm{~h}$ to detect changes in behavioral responses and also for tremors, convulsion, salivation, diarrhea, lethargy, sleep, coma and also were monitored up to 14 days for the toxic symptoms and mortality [15].

Evaluation hepatoprotective activity

TAA induced hepatotoxicity in rat's model [16-18] as used for evaluation of hepatoprotective activity for the plant extracts. The experimental design was as follows:

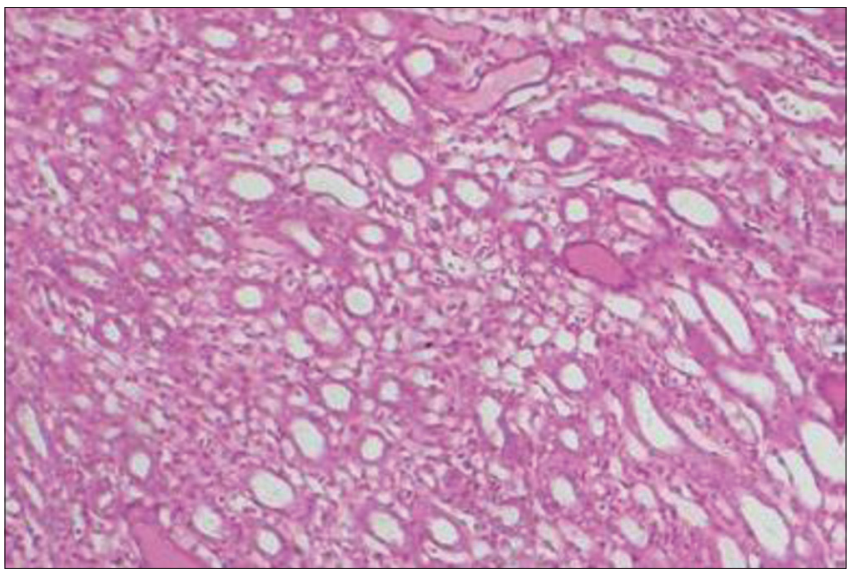

Figure 4: Histopathology of liver sample from TVME $(200 \mathrm{mg} / \mathrm{kg})$

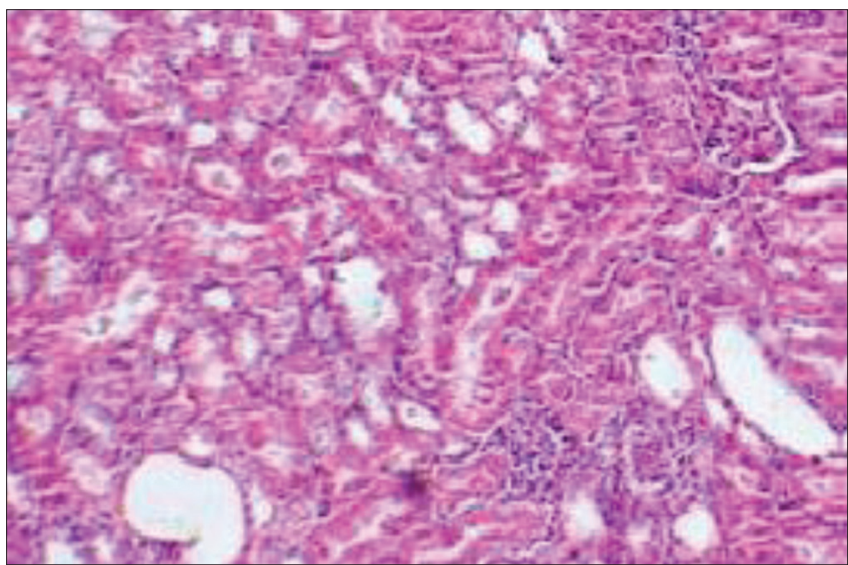

Figure 5: Histopathology of liver sample from TVME $(400 \mathrm{mg} / \mathrm{kg})$ 
- Group I: Treated with Saline (2 ml $/ \mathrm{kg})$, serves as normal control

- Group II: Positive or toxic control treated with TAA $(100 \mathrm{mg} / \mathrm{kg}$ b. w. s.c.) as a $2 \% \mathrm{w} / \mathrm{v}$ solution in water for injection on day $1^{\text {st }}$ and then normal saline for 21 days

- Group II: Standard group treated with TAA (100 mg/kg b. w., s.c.) as a $2 \% \mathrm{w} / \mathrm{v}$ solution in water for injection on day $1^{\text {st }}$ and then silymarin (25 mg/kg per day, p. o.) for 21 days

- Group IV: TVME $100 \mathrm{mg} / \mathrm{kg}$ group treated with TAA ( $100 \mathrm{mg} / \mathrm{kg}$ b.w., s.c.) as a $2 \% \mathrm{w} / \mathrm{v}$ solution in water for injection on day $1^{\text {st }}$ and then methanol extract of T. villosa (low dose) for 21 days

- GroupV:TVME $200 \mathrm{mg} / \mathrm{kg}$ group treated with TAA(100 mg/kg b.w., s.c.) as a $2 \% \mathrm{w} / \mathrm{v}$ solution in water for injection on day $1^{\text {st }}$ and then methanol extract of $T$. villosa (medium dose) for 21 days

- Group VI: TVME $400 \mathrm{mg} / \mathrm{kg}$ group treated with TAA ( $100 \mathrm{mg} / \mathrm{kg}$ b.w., s.c.) as a $2 \% \mathrm{w} / \mathrm{v}$ solution in water for injection on day $1^{\text {st }}$ and then methanol extract of T. villosa (high dose) for 21 days.

After 21 days of experimental period, blood sample had been collected individually for all the animals by retro-orbital puncture method and estimated for AST, ALT, ALP, total bilirubin, total protein, GPX, sodium and potassium. The clotting time was determined for blood samples by capillary tube method [17-19]. Later all the animals were sacrificed by cervical dislocation, liver samples were collected and the individual weights of the livers were estimated.

\section{Determination of antioxidant enzymes}

The liver samples were dissected out and washed using ice-cold saline solution. The pieces of liver samples were subjected to homogenization using tissue homogenizer with in $0.1 \mathrm{M}$ Tris- $\mathrm{Hcl}$ buffer (at pH 7.4). The homogenate was centrifuged and collected supernatant solution was used for the determination of liver antioxidant enzymes such as GPX, Catalase Peroxidase (CAP), Glutathione S-transferase (GST) and Glutathione reductase (GRD). The homogenate was also determined for activity of lipid peroxidation (LOP) in the liver.

\section{Histopathological evaluation}

At the end of research work, 2 animals from each group were sacrificed by euthanasia. After exsanguinations of the liver were removed immediately and washed with ice-cool saline, the liver samples were fixed with $10 \%$ formaldehyde, dehydrated in a graded series of alcohol, and embedded in paraffin wax before sectioning. The tissue was cut into sections approximately $5 \mu \mathrm{m}$ thick, dewaxed, and rehydrated. The sections were then stained with hematoxylin and eosin dye and studied for histopathological changes using a light microscope. Each sample was observed at a magnification of $100 \times$.

\section{Statistical analysis}

The data obtained from the study were subjected to statistical analysis by one-way ANOVA followed by Turkey multiple comparisons test, and results were expressed in terms of Mean \pm SEM values. Statistical analysis was performed using GraphPad Prism.

\section{RESULTS}

\section{Phytochemical investigation}

The methanol extract of T. villosa Linn. was subjected to different preliminary chemical tests to determine the chemical constituents present in the extracts. The results of study suggested that, methanol extracts consist of alkaloids, flavonoids, tannins, and phenolic compounds.

\section{Acute oral toxicity}

The results of acute oral toxicity study suggested that the extract of T. villosa that is TVME were safe up to $2000 \mathrm{mg} / \mathrm{kg}$. As per the above study, dose fixation was done and hence low dose was decided as $200 \mathrm{mg} / \mathrm{kg}$ and high dose was decided $400 \mathrm{mg} / \mathrm{kg}$ for the above extract.

\section{Evaluation of hepatoprotective activity}

Administration of plant extract has shown variations in various biochemical parameters in animals induced liver damage by TAA as follows:

\section{Effect of TVME on serum enzymes}

The serum enzymes ALT, AST, and ALP were significantly $(\mathrm{p}<0.001)$ elevated toxic control group due to administration of TAA compare to animals of normal group as a result liver damage while TVME $(200 \mathrm{mg} / \mathrm{kg}$ and $400 \mathrm{mg} / \mathrm{kg}$ ) and standard drug silymarin significantly $(p<0.001)$ reduced concentration serum enzymes in therapeutic animals. The effect of methanol extract was comparable standard drug and it was dose (Table 1).

Effect of TVME on direct bilirubin, total bilirubin and total bilirubin The administration of TAA induced hepatic injury serum direct bilirubin and total bilirubin were significantly increased in toxic control animals as compared to normal group of animals while there was significant $(p<0.001)$ reduction of direct bilirubin and total bilirubin was observed in animals treated with standard drug silymarin and TVME $(200 \mathrm{mg} / \mathrm{kg}$ and $400 \mathrm{mg} / \mathrm{kg}$ ) compared to toxic alone animals. The results were equivalent to normal the effect of methanol extract was dose dependent (Table 1)

In toxic control group animals administered with TAA, significant reduction of serum total protein and albumin was observed due to liver damage compared to normal animals but administration of silymarin and TVME $(200 \mathrm{mg} / \mathrm{kg}$ and $400 \mathrm{mg} / \mathrm{kg}$ ) caused dose dependent significant $(p<0.001)$ rise in total protein and albumin therapeutic group compared to toxic animals and the results (Table 2)

\section{Effect of TVME on serum ions}

TAA induced liver damage may cause ascites and hence there was significant reduction serum ionic concentration was observed in toxic control animals when compared to animals of normal group but serum ionic concentrations were significantly $(\mathrm{p}<0.001)$ increased in animals of therapeutic groups treated with silymarin and TVME $(200 \mathrm{mg} / \mathrm{kg}$ and $400 \mathrm{mg} / \mathrm{kg}$ ) when compared to toxic animals. The effect of extract was dose dependent and comparable to standard (Table 2).

Table 1: Effect of methanol extracts of Tephrosia villosa on serum enzymes and bilirubin against thioacetamide induced hepatotoxicity in rats

\begin{tabular}{|c|c|c|c|c|c|}
\hline \multirow[t]{2}{*}{ Treatment } & \multicolumn{5}{|c|}{ Serum parameters } \\
\hline & ALT (IU/ml) & AST (IU/ml) & $\operatorname{ALP}(\mathrm{IU} / \mathrm{ml})$ & Direct bilirubin (mg/dl) & Total bilirubin (mg/dl) \\
\hline Normal control & $62.35 \pm 2.342$ & $129.8 \pm 2.467$ & $78.53 \pm 2.170$ & $0.02633 \pm 0.001026$ & $0.3453 \pm 0.01345$ \\
\hline Standard (silymarin) & $63.00^{+++} \pm 3.543$ & $129.0^{+++} \pm 3.233$ & $85.33^{+++} \pm 3.299$ & $0.0752^{+++} \pm 0.005977$ & $0.3738^{+++} \pm 0.01314$ \\
\hline TVME $100 \mathrm{mg} / \mathrm{kg}$ & $320.1 \pm 165.0$ & $213.5 \pm 3.300$ & $192.9 \pm 3.327$ & $0.2563 \pm 0.01430$ & $0.8218 \pm 0.01133$ \\
\hline TVME $200 \mathrm{mg} / \mathrm{kg}$ & $129.1^{* *} \pm 2.770$ & $194.6^{* *} \pm 4.216$ & $130.0^{* *} \pm 1.201$ & $0.1289 * * \pm 0.003469$ & $0.6673^{* *} \pm 0.02521$ \\
\hline TVME $400 \mathrm{mg} / \mathrm{kg}$ & $84.85^{* * *} \pm 2.467$ & $127.6^{* * *} \pm 1.717$ & $83.23^{* * *} \pm 2.818$ & $0.06883^{* * *} \pm 0.004922$ & $0.3617^{* * *} \pm 0.01776$ \\
\hline
\end{tabular}

Values are mean \pm S.E.M, $\mathrm{n}=6$ symbols represent statistical significance. ${ }^{\mathrm{ns}} \mathrm{p}>0.05,{ }^{*} \mathrm{p}<0.05,{ }^{* *} \mathrm{p}<0.01,{ }^{* * *} \mathrm{p}<0.001$ versus diabetic control. ${ }^{\mathrm{ns}} \mathrm{p}>0.05,{ }^{+} \mathrm{p}<0.05,{ }^{++} \mathrm{p}<0.01$,

${ }^{++} \mathrm{p}<0.001$ normal control versus positive control. ALT: Alanine aminotransferase, AST: Aspartate aminotransferase, ALP: Alkaline phosphatase 
Effect of TVME on liver weight

Significant increase in weights of rat's liver was observed which may be due to damage induced by administration of TAA in toxic control animals as compared to normal animals. In animals treated with reference standard silymarin and TVME $(200 \mathrm{mg} / \mathrm{kg}$ and $400 \mathrm{mg} / \mathrm{kg}$ ), there was significant $(\mathrm{p}<0.001)$ reduction liver weight compared to toxic animals (Table 3)

\section{Effect of TVME on clotting time}

The prothrombin time was prolonged due to deficiency of clotting factors toxic animals compared to normal group as a result of TAA induced liver injury. The dose dependent significant $(\mathrm{p}<0.001)$ reduction in clotting time was observed animals treated with standard silymarin while TVME (200 mg/kg and $400 \mathrm{mg} / \mathrm{kg}$ ) (Table 3 ).

\section{Effect of TVME on GPX}

The serum antioxidant enzyme GPX level was significantly $(\mathrm{p}<0.001)$ raised by the administration of reference standard silymarin TVME (200 mg/kg and $400 \mathrm{mg} / \mathrm{kg}$ ) in therapeutic groups compared to animals of normal toxic group (Table 2).

\section{Liver antioxidant enzymes}

There was found to be significant $(\mathrm{p}<0.001)$ reduction concentration of liver antioxidant enzymes GPX, CAP, GSD, GRD, and LOP in toxic control animals treated with TAA alone compare to normal animals. While animals of therapeutic groups treated with silymarin and TVME (200 mg/kg and $400 \mathrm{mg} / \mathrm{kg}$ ), have exhibited significant $(\mathrm{p}<0.001)$ rise in liver antioxidant enzyme compare to toxic animals.

\section{Liver antioxidant enzymes}

There was found to be significant $(\mathrm{p}<0.001)$ reduction concentration of liver antioxidant enzymes GPX, CAP, GSD, GRD, and LOP in toxic control animals treated with TAA alone compare to normal animals. While animals of therapeutic groups treated with silymarin and TVME (200 mg/kg and $400 \mathrm{mg} / \mathrm{kg}$ ), have exhibited significant $(\mathrm{p}<0.001)$ rise in liver antioxidant enzyme compare to toxic animals (Table 3).

\section{Histopathological evaluation}

The administration of TAA was caused the complete loss of the normal architecture of livers in positive control animals with the appearance of vacuolated hepatocytes and degenerated nuclei. The pathological changes such as vacuolization, fatty degenerations, and coagulative necrosis of liver cells were found to be severe in the centrilobular region. The hepatotoxic metabolite TAA produced excessive formation and deposition of fibrous tissue and results in development of scars. The nodular transformation of rat liver treated with TVME $100 \mathrm{mg} / \mathrm{kg}$ has shown, large septa of fibrous tissue flowing together which penetrated into the parenchyma cells were found. However, sections of liver samples belongs to therapeutic groups treated with high doses of methanol extract showed almost normal lobular pattern with tiny and a mild degree of fatty degenerations, necrosis and infiltration of lymphocyte which was more or less comparable to the standard drug silymarin treated groups.

\section{DISCUSSION}

The fungicidal drug TAA get converted into potent hepatotoxins sulfine and sulfene metabolites after biotransformation in liver by cytochrome P450 systems which and produce centrilobular necrosis of hepatic cells. Administration of a single large dose of TAA $100 \mathrm{mg} / \mathrm{kg}$ is followed by degenerative changes in liver cells of rats leads to centrizonal necrosis. The pre-necrotic changes include loss of glycogen and acidophilic degeneration of cells in the central zone. The liver damage is always followed by disturbances in the several function of live such as metabolism of nutrients, storage functions, synthetic function, and detoxification process. [20-22].

The disturbance in the metabolism of carbohydrates, fats and proteins is main consequence of liver toxicity which leads to fatty change or fatty characterized by the deposition of fat in liver. Hence, the total weight of liver increases due to the deposition of fat and triglycerides in drug induced hepatic damage [22]. In the present study, weight of rat livers from toxic group was significantly increased due to TAA induced hepatic damage. However, administration of methanol extract and silymarin could able to normalize weight of livers in therapeutic groups indicates their liver protective properties.

Storage of various serum enzymes like ALT, AST and ALP is one of the important functions of liver. ALT and AST transaminases that are involved in transamination reactions of various amino acids while ALP is isoenzyme synthesized mainly by liver and has important role in dephosphorylation of biomolecules. These enzymes are leaked into blood in hepatotoxicity due to liver parenchymal damage and hence their concentrations in serum found to be elevated [23,24]. Another very

Table 2: Effect of methanol extracts of Tephrosia pumila, Tephrosia villosa, and Tephrosia calophylla on serum albumin, proteins and ions against thioacetamide induced hepatotoxicity in rats

\begin{tabular}{|c|c|c|c|c|c|}
\hline \multirow[t]{2}{*}{ Treatment } & \multicolumn{5}{|l|}{ Serum parameters } \\
\hline & Albumin (mg/dl) & Total protein (mg/dl) & Sodium (mE/L) & Potassium (mE/L) & Chlorides (mE/L) \\
\hline Normal control & $4.690 \pm 0.07358$ & $5.367 \pm 0.1175$ & $138.2 \pm 0.8504$ & $5.065 \pm 0.1428$ & $77.43 \pm 1.125$ \\
\hline Standard (silymarin) & $4.538 \pm 0.1914$ & $5.230 \pm 0.04712$ & $142.0 \pm 2.488$ & $5.007 \pm 0.1126$ & $80.35 \pm 1.431$ \\
\hline TVME $100 \mathrm{mg} / \mathrm{kg}$ & $2.407 \pm 0.1103$ & $3.293 \pm 0.08184$ & $81.05 \pm 0.4004$ & $2.423 \pm 0.05213$ & $132.0 \pm 2.598$ \\
\hline TVME 200 mg/kg & $3.615 \pm 0.05252$ & $3.857 \pm 0.1712$ & $103.5 \pm 1.630$ & $3.513 \pm 0.05308$ & $111.1 \pm 1.971$ \\
\hline TVME 400 mg/kg & $4.877 \pm 0.07233$ & $4.853 \pm 0.03547$ & $129.0 \pm 0.5275$ & $4.922 \pm 0.1027$ & $81.10 \pm 4.155$ \\
\hline
\end{tabular}

Table 3: Effect of methanol extracts of Tephrosia pumila, Tephrosia villosa, and Tephrosia calophylla on liver antioxidant enzymes and lipid peroxidase against thioacetamide induced hepatotoxicity in rats

\begin{tabular}{|c|c|c|c|c|c|c|}
\hline \multirow[t]{2}{*}{ Treatment } & \multicolumn{6}{|l|}{ Liver enzymes } \\
\hline & GPX (mg/G) & CAP (mg/G) & SOD (mg/G) & GST (mg/G) & GRD (mg/G) & LOP (mg/G) \\
\hline Normal control & $8.958 \pm 0.2643$ & $58.18 \pm 2.015$ & $9.351 \pm 1.0210$ & $7.092 \pm 0.4456$ & $4.045 \pm 0.3952$ & $7.490 \pm 0.1897$ \\
\hline Toxic control & $4.757^{+++} \pm 0.2648$ & $30.70^{+++} \pm 1.445$ & $5.467^{+++} \pm 1.411$ & $3.438^{+++} \pm 0.2230$ & $2.233^{+++} \pm 0.2441$ & $17.06^{+++} \pm 0.4039$ \\
\hline Standard (silymarin) & $8.132 * * * \pm 0.3254$ & $50.17^{* * *} \pm 1.118$ & $8.661^{* * *} \pm 1.334$ & $6.568 * * * \pm 0.4929$ & $3.852^{* * *} \pm 0.2376$ & $10.11^{* * *} \pm 0.2847$ \\
\hline TVME $200 \mathrm{mg} / \mathrm{kg}$ & $5.997^{* *} \pm 0.2139$ & $44.71^{* *} \pm 4.095$ & $7.119^{* *} \pm 1.632$ & $5.215^{* *} \pm 0.4532$ & $3.690^{* *} \pm 0.3902$ & $13.00 * * \pm 0.2515$ \\
\hline TVME 400 mg/kg & $8.212^{* * *} \pm 0.2416$ & $50.15^{* * * \pm 2.292}$ & $8.965^{* * *} \pm 1.184$ & $6.833^{* * *} \pm 0.2671$ & $4.130^{* * *} \pm 0.4354$ & $10.18^{* * *} \pm 0.4769$ \\
\hline
\end{tabular}

Values are mean \pm S.E.M, $n=6$ symbols represent statistical significance. ${ }^{n s} p>0.05,{ }^{*} p<0.05,{ }^{* *} p<0.01,{ }^{* * *} p<0.001$ versus diabetic control. ${ }^{n s} p>0.05,{ }^{+} p<0.05,{ }^{++} p<0.01$,

${ }^{++} \mathrm{p}<0.001$ normal control versus positive control.GPX: Glutathione peroxidase, CAP: Catalase peroxidase, GST: Glutathione S-transferase, GRD: Glutathione reductase,

LOP: Lipid peroxidation 
Table 4: Effect of methanol extracts of Tephrosia pumila, Tephrosia villosa, and Tephrosia calophylla on liver weights and prothrombin time against Thioacetamide induced hepatotoxicity in rats

\begin{tabular}{lll}
\hline Treatment & Liver weight(g) & Clotting time(s) \\
\hline Normal control & $5.963 \pm 0.07504$ & $191.2 \pm 7.087$ \\
Toxic control & $8.395^{+++} \pm 0.09691$ & $506.5^{+++} \pm 15.73$ \\
Standard(silymarin) & $6.017 \pm 0.1334$ & $191.3 \pm 5.737$ \\
TVME $100 \mathrm{mg} / \mathrm{kg}$ & $8.002 \pm 0.1190$ & $466.8 \pm 6.101$ \\
TVME $200 \mathrm{mg} / \mathrm{kg}$ & $7.510^{* *} \pm 0.05247$ & $354.5^{* *} \pm 9.468$ \\
TVME $400 \mathrm{mg} / \mathrm{kg}$ & $6.388 \pm 0.1512$ & $232.3 \pm 11.77$ \\
\hline
\end{tabular}

Values are mean \pm S.E.M, $n=6$ symbols represent statistical significance. ${ }^{\mathrm{n}} \mathrm{p}>0.05$, ${ }^{*} \mathrm{p}<0.05,{ }^{* *} \mathrm{p}<0.01,{ }^{* * *} \mathrm{p}<0.001$ versus diabetic control. ${ }^{\mathrm{n}} \mathrm{p}>0.05,{ }^{*} \mathrm{p}<0.05$,

${ }^{++} \mathrm{p}<0.01,{ }^{+++} \mathrm{p}<0.001$ normal control versus positive control

important role of liver is detoxification of bilirubin which is breakdown product of hem an iron component of hemoglobin. The bilirubin uptake by liver parenchyma cells from the blood and conjugates with glucoronic acid in presence of enzyme glucuronyl transferase. Later conjugated bilirubin gets excreted through bile. In liver, toxicity total bilirubin and direct bilirubin concentration are increased in serum due to reduced ability of liver parenchymal cells [25].

In our study, TAA administration caused elevated concentrations of ALT, AST, ALP, direct bilirubin and total bilirubin animals of toxic control which may be due to reduced function of liver due to toxicity. Treatment with silymarin and methanol extract significantly reduced serum concentrations of enzymes ALT, AST, and ALP indicating the enhanced storage function and also reduced bilirubin levels in blood shows the increased detoxification in therapeutic animals compared to toxic group which could be due to possible protection given by methanol extract.

Serum total protein, also called as total protein or plasma total protein is synthesized by the liver and is an important biochemical test for assessing liver function. The albumin and globulin that are produced in liver are the main components of total protein in the plasma [26]. In drug induced liver toxicity leads to reduction in total protein is observed due decreased albumin synthesis due to cirrhosis. In present study in toxic animals treated with TAA, the significant reduction of serum albumin and total protein was observed while total protein and serum albumin level was increased by methanol extract treated animals indicated its ability to reverse the hepatic damage caused by TAA.

The two main complications of hepatotoxicity are ascites and edema which are due to accumulation of fluids in extravascular sites of the body. In these complications serum ions sodium, potassium and chlorides moves of blood into extravascular tissues and hence finally lead to reduction in these ionic concentrations in blood [25]. In our study, serum ionic concentrations were decreased in toxic group treated while animals treated with methanol extract and silymarin exhibited significant increase of ions sodium, potassium and potassium which shows property of the methanol extract to reduce ascites and edema may be by regenerating the liver cells.

The liver produces all the clotting factors associated with blood clotting mechanism, and it has main role in regulating normal prothrombin time or clotting time. In liver disorders synthesis of clotting factors will be affected and hence clotting time is prolonged [25]. In our esteemed study, animals induced with liver damage by TAA administration have shown prolonged clotting time. However, animals treated with silymarin and methanol extract have shown significant decrease in clotting time compared to positive toxic animals indicating that methanol extract can reverse complications of hepatotoxicity.

The GPX is antioxidant enzyme synthesized by liver involved in the neutralization of free radicals. In the present study, the administration of silymarin and methanol extract significantly increased the amount of GPX in the therapeutic groups compared to toxic animals. This shows the potential of the methanol extract to increase the concentration of GPX and protects the liver cells against TAA induce free radical mediated effects.

Examinations histopathological of liver samples in toxic control group produced granular degenerations, fatty changes and inflammatory responses. Some toxicants also show coagulative necrosis, degenerative necrosis and bile duct hyperplasia. Coagulative type of necrosis is the most common type of necrosis caused by irreversible focal injury mostly due to sudden cessation of blood flow, ischemia. In present study histopathology of liver samples has shown marked reduction in fatty degeneration and necrosis in animal groups treated with standard drug silymarin and extract TVME. It is evident that the methanol extract caused regeneration of parenchyma cells of liver had hepatic cell damage caused due to TAA toxicity.

The ability of the living system to counteract free radical mediated damages is natural antioxidant mechanism in which GPX, CAP, GST, GRD and lipid peroxidase are produced in the affected organ/tissue. In the present study, there was significant increase in the synthesis of liver antioxidant enzymes found in animals treated with TVME indicating its potential to protect the liver cells against TAA induced free radical damage.

The drug induced hepatotoxicity is mainly due to oxidative stress and free radicals mediated damage [22]. Hence, free radical scavenging and antioxidant mechanisms are more important to reverse or prevent drug induced liver toxicity. The extracts of T. villosa had been reported for its antioxidant activity. In the present study, methanol extract of T. villosa could reduce the most of the complications of TAA induced hepatotoxicity and also significantly increased liver antioxidant enzymes such as GPX, CAP, GST, GRD, and lipid peroxidase which may be the possible mechanism of action of extract. Further, studies are required to correlate the hepatoprotective potentials of the extract with increased glutathione concentrations and also to isolate and evaluate hepatoprotective principle from the methanol extract [26].

Hence in conclusion, the possible mechanism of beneficia

liver protecting property of our extract due to its potent antioxidant activity. The histopathological studies supported the results of biochemical tests, showing less damage in the cytoarchitecture of the liver.

CONCLUSION

The results obtained from estimation of biochemical parameters suggesting that methanol extract of T. villosa leaves posses significant hepatoprotective property in TAA induced liver toxicity in rats model.

\section{ACKNOWLEDGMENTS}

The authors of manuscript are thankful to the principal and management of East West College of Pharmacy, Bangalore for providing facilities to conduct this research work.

\section{AUTHORS CONTRIBUTIONS}

All the authors have equal contribution in the present research work.

\section{CONFLICT OF INTEREST}

We hereby declare that there is no conflict of interests.

\section{ATHORS FUNDING}

The present research work is not funded by any other external agency.

\section{REFERENCES}

1. Rajesh MG, Latha MS. Preliminary evaluation of the anti-hepatotoxic activity of Kamilari, a polyherbal formulation. J Ethnopharmacol 2004;91:99-104.

2. Ramachandra SS, Absar AQ, Swamy AH, Tushar PP, Prabhu K, Veeran GA. Hepatoprotective activity of Calotropis procera flowers against paracetamol-induced hepatic injury in rats. Fitoterapia 
$2007 ; 8: 451-4$

3. Subramaniam A, Pushpangadan P. Development of Phytomedicine for liver disease. Ind J Pharmacol 1999;31:166-75.

4. Bahar A, Tanveer A, Shah AK. Hepatoprotective activity of Luffa echinata fruits. J Ethnopharmacol 2001;76:187-9.

5. Yoganarasimhan SN. Medicinal Plants of India, Tamilnadu. Vol. 2. Cyber Media. p. 30-1.

6. Sethiya NK, Nahata A, Mishra SH, Dixit VK. An update on shankhpushpi, a cogntition-boosting ayurvedic medicine. Zhong Xi Yi Jie He Xue Bao 2009; 7:1001-22.

7. Gholap S,Kar A. Hypoglycaemic effects of some plant extracts are possibly mediated through inhibition in corticosteroid concentration. Pharmazie 2004;59:876-8

8. Anxiolytic Activity of Convolvulus pluricaulis. Available from: http:// michaelmazur.net/xml.php

9. Sairam K, Rao CV, Goel RK. Effect of Convolvulus pluricaulis Chois on gastric ulceration and secretion in rats. Ind J Exp Biol 2001;39:350-4.

10. Nahata A, Patil UK, Dixit VK. Anxiolytic activity of Evolvulus alsinoides and Convulvulus pluricaulis in rodents. Pharm Biol 2009; 47:444-51.

11. Prasad SB, Sharma A. Antioxidant activity of Convolvus plauricalis. Invent Rapid Plant Act 2011;79:29.

12. Kokate CK. Practical Pharmacognosy. New Delhi: Vallabh Prakashan; 1994;4:110-1.

13. Trease GE, Evans MC. Text Book of Pharmacognosy. London: Bailliare Tindall; 1983. p. 12. p. 193, 336.

14. Khandelwal KR. Practical Pharmacognosy-techniques and Experiments. Pune: Nirali Prakashan; 2000

15. OECD 2001-gudeline on Acute Oral Toxicity (AOT) Environmental Health and Safety; 2001

16. Aftab A, Pillai KK, Abul KN, Shibli JA, Pal SN Evaluation of hepatoprotective potential of jigrine post-treatment against thioacetamide induced hepatic damage. J Ethnopharmacol
2002;79:35-41.

17. Aftab A, Pillai KK, Abul KN, Shibli JA, Pal SN, Balani DK. Evaluation of hepatoprotective potential of jigrine post-treatment against thioacetamide induced hepatic damage. J Ethnopharmacol 2002; $79: 35-41$

18. Kumar G, Banu GS, Pappa PV, Sundararajan M, Pandian MR. Hepatoprotective activity of Trianthema portulacastrum L. against paracetamol and thioacetamide intoxication in albino rats. J Ethnopharmacol 2004;92:37-40.

19. Kamlesh S, Nisha S, Anish C, Ashish M. In vivo antioxidant and hepatoprotective activity of methanolic extracts of Daucus carota seeds in experimental animals. Asian Pac J Trop Biomed 2012;2:385-8.

20. Sabrina F, Ching-Feng W. Co-administration of cyclosporine alleviates thioacetamide induced liver injury. World J Gastroenterol 2005;11:1411-9.

21. Ramaiah SK, Apte U, Mehendale HM. Cytochrome P4502E1 induction increases thioacetamide liver injury in diet restricted rats. Drug Metab Dispos 2001;29:1088-95

22. Shapiro H, Ashkenazi M, Weizman N, Shahmurov M, Aeed H, Bruck R. Curcumin ameliorates acute thioacetamide induced hepatotoxicity. J Gastroenterol Hepatol 2006;21:358-66.

23. Mohan H. The liver, biliary tract, exocrine and pancreas: Textbook of Pathology. $4^{\text {th }}$ ed. New Delhi: Jaypee Brothers Medical Publishers (P) Ltd.; 2002. p. 22-4, 569-80.

24. Aftab A, Pillai KK, Abul KN, Shibli JA, Pal SN, Balani DK Evaluation of hepatoprotective potential of jigrine post-treatment against thioacetamide induced hepatic damage. J Ethnopharmacol 2002;79:35-41

25. Satyanarayana U, Chalrapani U. Liver Function Tests. Fundamentals of biochemistry Kolkata; 2006:453-8

26. Hallwll B, Jonh MC. Free Radicals in Biology and Medicine: Gutteridge Protection against Free Radical Damage. $2^{\text {nd }}$ ed. Oxford: Clarendon Press; 1989. p. 334-9. 